\title{
Identification of a cDNA from the Arbuscular Mycorrhizal Fungus Glomus intraradices that is Expressed During Mycorrhizal Symbiosis and Up-Regulated by $\mathbf{N}$ Fertilization
}

\author{
Juan M. Ruiz-Lozano, Carlos Collados, Rosa Porcel, Rosario Azcón, and José M. Barea \\ Departamento de Microbiología del Suelo y Sistemas Simbióticos. Estación Experimental del Zaidín (CSIC), Profesor \\ Albareda no 1, E-18008 Granada, Spain
}

Submitted 6 August 2001. Accepted 3 January 2002.

\begin{abstract}
A cDNA library was constructed with RNA from Glomus intraradices-colonized lettuce roots and used for differential screening. This allowed the identification of a cDNA (Gi-1) that was expressed only in mycorrhizal roots and was of fungal origin. The function of the gene product is unknown, because Gi-1 contained a complete open reading frame that was predicted to encode a protein of 157 amino acids which only showed little homology with glutamine synthetase from Helicobacter pylori. The time-course analysis of gene expression during the fungal life cycle showed that Gi-1 was expressed only during the mycorrhizal symbiosis and was not detected in dormant or germinating spores of $G$. intraradices. P fertilization did not significantly change the pattern of Gi-1 expression compared with that in the unfertilized treatment, whereas $\mathbf{N}$ fertilization (alone or in combination with $P$ ) considerably enhanced the Gi-1 transcript accumulation. This increase in gene expression correlated with plant $N$ status and growth under such conditions. The possible role of the $\mathrm{Gi}-1$ gene product in intermediary $\mathrm{N}$ metabolism of arbuscular mycorrhizal symbiosis is further discussed.
\end{abstract}

Additional keywords: AM symbiosis, drought stress, N metabolism.

The arbuscular mycorrhizal (AM) symbiosis is formed between the roots of most higher plants and Zygomycete fungi belonging to the order Glomales. It is estimated that more than $80 \%$ of land plants can form this type of association, including many agriculturally and horticulturally important crop species (Smith and Read 1997). This mutualistic association has probably existed for approximately 450 million years, since the colonization of land by ancient plants, and remains a crucial factor for sustainability of most terrestrial ecosystems (Pyrozynsky and Malloch 1975). Despite the widespread occurrence of AM symbiosis, the AM fungi are obligate biotrophs who depend on their ability to colonize a host plant for completion of their life cycle (Smith and GianinazziPearson 1988).

Corresponding author: Juan M. Ruiz-Lozano, Telephone. +34 958121011; Fax: + 34958 129600; E-mail: juanmanuel.ruiz@eez.csis.es

The nucleotide sequence corresponding to Gi-1 cDNA has been deposited in the EMBL database under accession number AJ315337.
Colonization of the root system by AM fungi confers benefits directly on host plant growth and development, through the acquisition of phosphate and other mineral nutrients from the soil, such as N, Cu, or Zn (Smith and Read 1997). In addition, colonization also enhances plant resistance to biotic and abiotic stresses (Newsham et al. 1995; Ricken and Hofner 1996; Ruiz-Lozano et al. 1995, 2001). These beneficial effects of AM symbiosis on the host plant occur as the result of a complex molecular dialogue between the two symbiotic organisms (Harrier 2001). Morphogenetic changes in both plant and fungus during colonization indicate that there must be an exchange of signals between the partners, with regulation occurring at several control points (Barker et al. 1998). The AM symbiosis lacks host specificity; therefore, it has been suggested that either the signal molecules are conserved throughout the plant kingdom or that a broad range of related compounds might be involved (Koide and Schreiner 1992). The final outcome is a functional mycorrhizal root, in which metabolic activity of the two symbionts is regulated and is presumably under the control of genes from both symbionts. Identifying the molecules and genes involved in the dialogue between or within the host plant and within the AM fungus is a prerequisite for a better understanding of the ecological fitness of the symbiosis.

Molecular details of mycorrhiza development and functioning are now becoming experimentally tractable. The molecular identification of recently discovered symbiosis-regulated (SR) genes and the analysis of mycorrhiza mutants, along with new experimental approaches, such as subtractive and differential hybridization of cDNA libraries, and innovative applications of older technologies, such as nuclear magnetic resonance, are together generating a conceptual framework for understanding the formation and physiology of mycorrhizae (Martin 2001). Numerous plant genes showing differential expression during mycorrhizal symbiosis have been identified in the last few years (Burleigh and Harrison 1997; Krajinski et al. 2000; Liu et al. 1998; Martin-Laurent et al. 1997; Murphy et al. 1997; Ruiz-Lozano et al. 1999; van Buuren et al. 1999). Similarly, AM fungal genes also have been identified (Burleigh and Harrison 1998; Ferrol et al. 2000; Franken and GianinazziPearson 1996; Franken and Requena 2001; Franken et al. 1997; Harrier 2001; Requena et al. 2000), but few of them have been demonstrated to play a functional role during the symbiosis. One of the most important fungal genes discovered so far may be a fungal (Glomus versiforme) phosphate transporter assumed to be responsible for initial $\mathrm{P}$ uptake by the 
fungus from the soil matrix (Harrison and van Buuren 1995). Besides this specific example, other fungal genes that are expressed during the symbiotic phase also have been identified (Delp et al. 2000; Harrier et al. 1998; Kaldorf et al. 1998; Lanfranco et al. 1999; Sawaki and Saito 2001).

The identification of genes from AM fungi has been especially difficult, however, because of the obligate symbiotic nature of these fungi. This limits the amount of fungal material available, which can be obtained only from spores or extraradical hyphae. In addition, the quantity of living AM fungal material inside roots is very small in comparison with other plant-microbe interactions. Approximately $1 \%$ of the mRNA extracted from highly colonized roots belongs to the fungal partner, hindering the discovery of fungal genes with low expression (Franken and Requena 2001).

Here, we report the differential screening of a cDNA library from mycorrhizal roots and the identification of a fungal gene that was expressed during the AM symbiotic phase and that was up-regulated by $\mathrm{N}$ fertilization. The effect of drought stress on the pattern of gene expression also was analyzed.

\section{RESULTS}

\section{Mycorrhizal infection.}

Aliquots of roots colonized by $G$. intraradices used for construction of the cDNA library were stained with trypan blue to assess the mycorrhizal colonization. The roots were heavily colonized with $94 \%$ of colonization frequency, $68 \%$ of colonization intensity, and $78 \%$ of arbuscule abundance (Table 1). Neither $\mathrm{N}$ and $\mathrm{P}$ fertilization nor drought stress affected the mycorrhizal infection levels reached on lettuce roots by $G$. intraradices compared with the well-watered unfertilized treatment. Similarly, soybean plants were not affected in the percentage of mycorrhizal root length either by the presence of Bradyrhizobium japonicum or by drought stress (Table 2). Only dually inoculated and well-watered soybean plants showed a significantly higher intensity of colonization and arbuscule abundance than the corresponding well-watered nonnodulated treatment.

\section{Isolation of a differentially expressed cDNA clone and expression in mycorrhizal roots.}

After a first round of screening, several independent phage clones were isolated, representing genes theoretically upregulated in lettuce roots during AM symbiosis. At this stage, a polymerase chain reaction (PCR)-based screening strategy was adopted because, when combined with Southern blotting analysis, it provided an additional check of the induction or repression of the clones under investigation (Martin-Laurent et al. 1995). Seven clones were amplified by PCR with universal M13 primers. Only one of the clones gave two PCR products, indicating that it contained two phage populations. The PCR products were separated on agarose gels to make replica filters

Table 1. Mycorrhizal colonization reached by Glomus intraradices ${ }^{\mathrm{z}}$

\begin{tabular}{lccl}
\hline Fertilization & $\boldsymbol{F ( \% )}$ & $\boldsymbol{M}(\boldsymbol{\%})$ & $\boldsymbol{A}(\boldsymbol{\%})$ \\
\hline$+\mathrm{N}$ & $95.5 \mathrm{a}$ & $70.2 \mathrm{a}$ & $81.9 \mathrm{ab}$ \\
+P & $94.9 \mathrm{a}$ & $63.4 \mathrm{a}$ & $77.9 \mathrm{~b}$ \\
+NP & $95.0 \mathrm{a}$ & $61.3 \mathrm{a}$ & $87.6 \mathrm{a}$ \\
Unft. (Ww) & $94.1 \mathrm{a}$ & $68.1 \mathrm{a}$ & $78.8 \mathrm{~b}$ \\
Unft. (D) & $92.1 \mathrm{a}$ & $70.0 \mathrm{a}$ & $80.8 \mathrm{ab}$ \\
\hline
\end{tabular}

${ }^{\mathrm{z}}$ On roots of lettuce plants fertilized with $4 \mathrm{mM} \mathrm{N}$ or $0.5 \mathrm{mM} \mathrm{P}$, or both, or on unfertilized lettuce roots either well-watered (Ww) or drought stressed (D). $F=$ colonization frequency, $M=$ colonization intensity, and $A=$ arbuscule richness. Numbers in a column followed by the same letter are not significantly different $(P<0.05)$ as determined by Duncan's multiple range test. which were hybridized with radiolabeled cDNA from $G$. intraradices-colonized roots or from uninoculated control roots. After hybridization, one out of the seven clones was confirmed as differentially expressed, representing a gene (Gi-l) upregulated in lettuce roots during AM symbiosis.

Northern blot analysis using RNA from nonmycorrhizal or mycorrhizal ( $G$. mosseae and $G$. intraradices) lettuce roots cultivated under either well-watered conditions or droughtstress conditions showed that the Gi-1 cDNA probe hybridized to a $0.66-\mathrm{kb}$ transcript that was present exclusively in $G$. intraradices-colonized roots (Fig. 1). Drought stress decreased Gi-1 transcript accumulation by 1.8 -fold. No signal of transcript accumulation was detected in control or G. mosseae-colonized plants. Additional Northern hybridization using RNA from control or $G$. intraradices-colonized maize roots also showed a clear hybridization signal on RNA from $G$. intraradices-colonized maize roots cultivated under well-watered conditions, while drought decreased gene expression to undetectable levels (data not shown).

\section{Genomic origin of Gi-1.}

Although Northern blotting experiments with lettuce and maize RNA suggested a possible fungal origin of the gene, it was necessary to unequivocally determine its genomic origin. A PCR-based approach was selected. Specific primers were designed on the basis of the Gi-1 sequence and used in PCR amplification with genomic DNA from lettuce leaves, lettuce roots colonized by $G$. mosseae, lettuce and pea roots colonized by $G$. intraradices, and spores of $G$. intraradices. A band of approximately $350 \mathrm{bp}$ was amplified on genomic DNA from lettuce and pea roots colonized by $G$. intraradices, as well as from spores of that fungus (Fig. 2A). Positive reactions carried out with the same DNA using primers ITS1/ITS4 successfully amplified all of the DNA tested (data not shown). The PCR fragment amplified from the genomic DNA (350 bp) was larger than that amplified from the cDNA control plasmid (268 bp), indicating that the primer pair had been designed at both sides of an intron of approximately $80 \mathrm{bp}$. In all cases, the

Table 2. Mycorrhizal colonization reached by Glomus intraradices ${ }^{\mathrm{Z}}$

\begin{tabular}{llll}
\hline Inoculation & $\boldsymbol{F ( \% )}$ & $\boldsymbol{M ( \% )}$ & $\boldsymbol{A}(\boldsymbol{\%})$ \\
\hline Gi Ww & $88.0 \mathrm{a}$ & $41.5 \mathrm{~b}$ & $73.8 \mathrm{~b}$ \\
Gi+Br Ww & $96.0 \mathrm{a}$ & $76.5 \mathrm{a}$ & $89.3 \mathrm{a}$ \\
Gi D & $87.0 \mathrm{a}$ & $55.0 \mathrm{ab}$ & $93.3 \mathrm{a}$ \\
Gi+Br D & $86.0 \mathrm{a}$ & $52.0 \mathrm{ab}$ & $98.0 \mathrm{a}$ \\
\hline
\end{tabular}

${ }^{\mathrm{z}}$ On soybean co-inoculated $(\mathrm{Gi}+\mathrm{Br})$ or not $(\mathrm{Gi})$ with Bradyrhizobium japonicum and cultivated under well-watered (Ww) conditions or subjected to drought (D). $F=$ colonization frequency, $M=$ colonization intensity, and $A=$ arbuscule richness. Numbers in a column followed by the same letter are not significantly different $(P<0.05)$ as determined by Duncan's multiple range test.

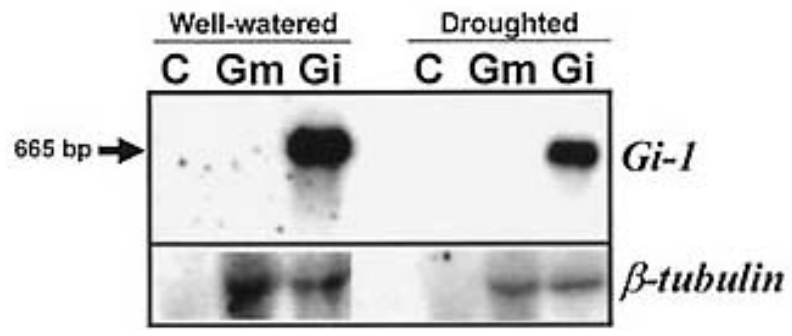

Fig. 1. Northern blot of root total RNA $(15 \mu \mathrm{g})$ from uninoculated control (C) or mycorrhizal (Glomus mosseae [Gm] or G. intraradices [Gi]) lettuce plants cultivated under well-watered or drought-stressed conditions. Blots were hybridized with the Gi-1 probe and with the $G$. intraradices $\beta$ tubulin. 
amplified fragments hybridized with the Gi-1 cDNA probe (Fig. 2B).

\section{Sequence analysis of $\mathrm{Gi}-1$ gene.}

The phage clone containing the Gi-1 cDNA was in vivo excised and the phagemids recovered and purified for storage and sequencing with universal M13 forward and reverse primers. The Gi- 1 cDNA was 665 bp long, including a poly A tail at the $3^{\prime}$ end, and the guanine plus citosine content was $36 \%$, similar to the content described in other genes of $G$. intraradices (Sawaki and Saito 2001) or from Gigaspora rosea (Stommel et al. 2001). Gi-1 contained a complete open reading frame (ORF) that was predicted to encode a protein of 157 amino acids (Fig. 3). Sequence analysis using BLAST and FASTA software revealed that Gi-1 was novel and does not share significant similarity with any sequences in data bases. However, a region of the putative protein encoded by this cDNA showed $33 \%$ identity with glutamine synthetase from Helicobacter pylori, although this similarity was of low significance (Fig. 3).

\section{Time-course of Gi-1 expression during AM symbiosis.}

Northern analysis suggested that expression of Gi-1 mRNA in the fungus was dependent upon interactions with the roots; therefore, we investigated the temporal expression of the $G i-1$ gene during presymbiotic fungal phases and during the interaction with lettuce roots. Gi-1 transcript levels were analyzed by reverse transcription (RT)-PCR in ungerminated and germinating spores of $G$. intraradices and by Northern blot in lettuce roots during the development of the AM symbiosis. RTPCR did not lead to amplification of any cDNA fragment from ungerminated or germinating spores, suggesting that, in these phases, the corresponding gene was not expressed (Fig. 4). Positive control reactions for RT-PCR using ribosomal primers designed on the $18 S$ gene were run in parallel. A band of the right size $(550 \mathrm{bp})$ was amplified for the three cDNA samples, whereas no band was revealed for the RT minus reaction. Northern blot experiments showed increasing gene expression as the symbiosis progressed (Fig. 5). In fact, lettuce roots were progressively colonized by $G$. intraradices, and the colonization levels increased from $27 \%$ of the root length at 7 days after inoculation (dai) to $92 \%$ at 35 dai (Table 3). The increase in

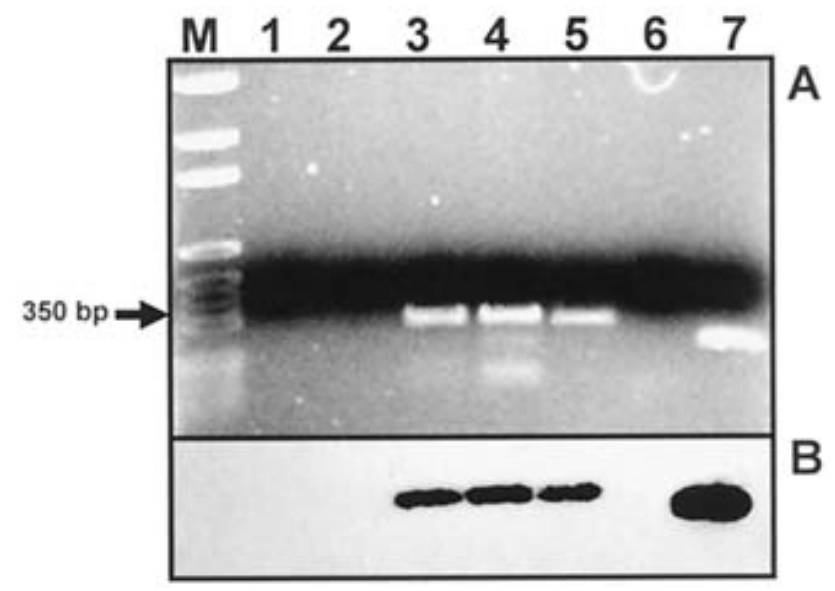

Fig. 2. A, Electrophoresis on $1.2 \%$ agarose gel for polymerase chain reaction products obtained with specific primers designed on Gi-1 sequence and genomic DNA of different origins. B, Southern blot hybridization using the Gi-1 cDNA insert as a probe. M, pGEM marker; lane 1, lettuce leaves; lane 2, lettuce roots colonized by Glomus mosseae; lane 3, lettuce roots colonized by $G$. intraradices; lane 4, pea roots colonized by $G$. intraradices; lane 5, spores of G. intraradices; lane 6, no-DNA control; lane 7, positive control (plasmid containing Gi-1 cDNA insert). root colonization matched perfectly with the increases in gene expression. It reached the maximum transcript levels 35 dai, coinciding with the highest intensity of colonization.

\section{Analysis of Gi-1 expression after $\mathbf{N}$ or $\mathbf{P}$ fertilization.}

The main role of the AM symbiosis has traditionally been attributed to increases in the plant phosphate status and, more recently, also in plant N status (Smith and Read 1997). To determine whether Gi-1 transcripts show regulation in response to phosphate or nitrogen nutrition, the transcript levels were examined in root RNA from lettuce plants fertilized with $\mathrm{P}$ or $\mathrm{N}$. We observed that $\mathrm{P}$ fertilization did not significantly change the pattern of Gi-1 transcript accumulation compared with the corresponding unfertilized mycorrhizal plants (Fig. 6). In contrast, $\mathrm{N}$ application increased the amount of $\mathrm{Gi}-1$ transcript present in the mycorrhizal roots 2.5 -fold; this also was evident when $\mathrm{N}$ and $\mathrm{P}$ fertilization was combined. This effect had a clear correlation with the root $\mathrm{N}$ concentration and plant growth (Fig. 7). In fact, P-fertilized plants did not increase plant growth or root $\mathrm{N}$ concentration with respect to unfertilized plants, whereas $\mathrm{N}$ application (alone or in combination with $\mathrm{P}$ ) increased both root $\mathrm{N}$ concentration and plant growth.

\section{Gi-1 expression in soybean roots inoculated with $G$. intraradices only or in dual symbiosis with the AM fungus and Bradyrhizobium japonicum and subjected or not to drought stress.}

We analyzed the transcript levels in soybean plants inoculated with $G$. intraradices only or dually infected by the AM fungus and by B. japonicum. Plants were either well-watered or drought-stressed before harvest. Results from Northern blot analysis showed that the Gi-1 transcript levels increased 1.9fold in well-watered plants dually inoculated with the AM fungus and $B$. japonicum, compared with the corresponding nonnodulated mycorrhizal plants (Fig . 8). This increase coincided with a significantly higher intensity of colonization (M\%) and arbuscule richness $(\mathrm{a} \%)$ in these dually colonized roots compared with the mycorrhizal roots alone (Table 2) and also with a higher $\mathrm{N}$ content of the dually inoculated plants (RuizLozano et al. 2001). In both microbial treatments, drought stress decreased the transcript levels 1.9-fold compared with the corresponding well-watered plants, but the dually inoculated plants continued showing increased Gi-1 transcript levels with respect to the nonnodulated plants. The decrease in transcript levels due to drought was not accompanied by a significant decrease in any of the mycorrhizal parameters (Table 2). The effect of drought observed in soybean was similar to that already observed in lettuce plants.

\section{DISCUSSION}

The development of a functional AM symbiosis requires a complex series of interactions between the two symbionts. After root colonization, the fungal partner invades and differentiates within the cortical cells of the root to form arbuscules that are assumed to represent the nutrient exchange sites between the two symbionts (Alexander et al. 1988; Smith and Smith 1990). Although the process of colonization has been clearly described, the molecular mechanisms underlying the development and functioning of the AM symbiosis are still largely unknown (van Buuren et al. 1999). Identification of the primary genetic determinants controlling the formation and metabolic activity of the mycorrhizal symbiosis (i.e., $\mathrm{P}$ and $\mathrm{N}$ scavenging) will open the door to understanding its function. However, this symbiosis adds an additional layer of complexity to the 
challenge of designing experimental systems and framing questions and, thus far, it has been relatively difficult to study these primary genetic determinants (Martin 2001).

In this study, we report the differential screening of a cDNA library constructed with RNA from mycorrhizal lettuce roots and the identification of a cDNA (Gi-1) which is expressed only in mycorrhizal roots. By means of a PCR-based approach, we have demonstrated that Gi-1 is of fungal origin. It contains a complete ORF that is predicted to encode a protein of 157 amino acids that shows only weak homology with glutamine synthetase from $H$. pylori. Hence, the real function of the gene product is unknown. The time-course analysis of the gene expression during the fungal life cycle showed that Gi-1 was expressed only during the mycorrhizal symbiosis, and we could not detect $G i-1$ gene expression either in dormant or in germinating spores of $G$. intraradices. The level of Gi-1 transcripts increased as the fungus colonized the roots of the host plant. The maximum gene expression coincided with the highest intensity of colonization. It may be thought that we are detecting a constitutive fungal gene and that the higher the amount of fungal biomass in the colonized roots, the more transcripts accumulate. However, data from plants subjected to drought do not support this idea. In fact, drought did not affect mycorrhizal development in terms of colonization frequency, colonization intensity, or arbuscule richness, but Gi-1 transcript levels decreased by nearly twofold in lettuce and soybean plants colonized by $G$. intraradices (a similar effect of drought was observed in Northern experiments with maize plants colonized by $G$. intraradices [data not shown]). Similarly, $\mathrm{N}$ fertilization did not change levels of mycorrhizal infection but enhanced the level of Gi-1 transcript accumulation. Hence, we consider that Gi-1 cDNA corresponds to a gene with an active role in the functioning of the mycorrhizal symbiosis.

Data from northern experiments with $\mathrm{N}$ - or P-fertilized lettuce plants colonized by $G$. intraradices showed that $\mathrm{P}$ fertilization did not change significantly the pattern of Gi-1 expression compared with that of the unfertilized treatment, whereas $\mathrm{N}$ fertilization enhanced Gi-1 transcript accumulation consid- erably. The increase in gene expression correlated with root $\mathrm{N}$ status and plant growth under such conditions. This suggests that the Gi-1 gene may be related to $\mathrm{N}$ metabolism in the mycorrhizal symbiosis. The two most important sources of inorganic $\mathrm{N}$ for plants, and potentially for $\mathrm{AM}$ fungi, are nitrate and ammonium ions. In this study, $\mathrm{NH}_{4} \mathrm{NO}_{3}$ was used as a source for $\mathrm{N}$ although, because of the rapid nitrification of ammonium that occurs in agricultural soils, nitrate is expected to have been the main $\mathrm{N}$ source for these plants. For its assimilation, nitrate has to be reduced to ammonia in order to be incorporated into organic structures and to fulfill its essential functions as a plant nutrient. The reduction of nitrate to ammonia is mediated by two separated enzymes: nitrate reductase, which reduces nitrate to nitrite; and nitrite reductase, which reduces nitrite to ammonia. However, ammonia is toxic at quite low concentrations and has to be incorporated into organic compounds in the roots (Marschner 1986). The formation of amino acids, amides, and related compounds is the main pathway of detoxification of ammonia. In this pathway, the amino acid glutamate acts as the receptor for ammonia and the amide glutamine is formed by the enzyme glutamine synthetase. Then, the organically bound nitrogen of glutamate and glutamine can be utilized for the synthesis of other amides, as well as of ureides, amino acids, and high-molecular-weight compounds such as proteins (Marschner 1986).

A number of studies recently have demonstrated the importance of AM symbiosis for the $\mathrm{N}$ status of the host plant (Azcón et al. 1992, 1996; Faure et al. 1998; Johansen 1999; Johansen et al. 1993; Mäder et al. 2000; Tobar et al. 1994a, 1994b), although little is known about the genetic determinants involved in such functions. In fact, AM fungi seem to possess the enzymatic machinery involved in $\mathrm{N}$ metabolism. So far however, only the gene coding for a nitrate reductase (NR) has been identified in DNA from spores of $G$. intraradices (Kaldorf et al. 1994). Later in situ hybridization located the fungal NR in arbuscules but not in vesicles, suggesting differential fungal gene expression in the symbiotic state (Kaldorf et al. 1998). The demonstration that nitrate reduction occurs in arbuscules of AM fungi implies that these

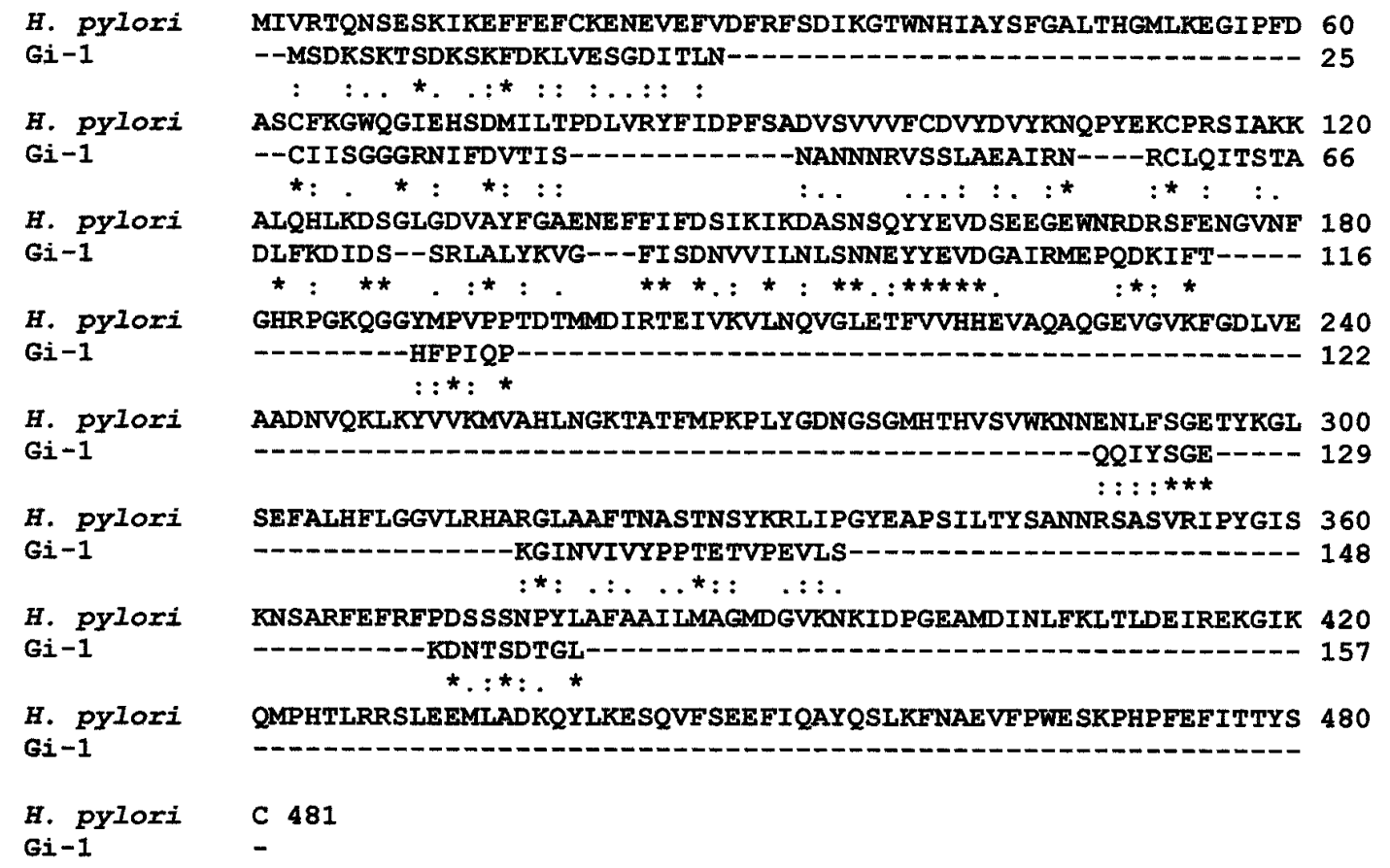

Fig. 3. Alignment between glutamine synthetase from Helicobacter pylory and the putative protein encoded by the Gi-1 gene. Asterisks (*) indicate identical amino acids and colons (:) or periods (.) indicate similar amino acids. 
fungi must have other enzymes involved in $\mathrm{N}$ metabolism (Burleigh 2000).

A picture similar to that obtained in $\mathrm{N}$-fertilized lettuce plants was observed in soybean plants dually inoculated with $G$. intraradices and B. japonicum compared with the corresponding nonnodulated mycorrhizal plants. Despite the fact that nonnodulated plants were fertilized with $3 \mathrm{mM}$ of $\mathrm{NH}_{4} \mathrm{NO}_{3}$, the nodulated plants showed higher $\mathrm{N}$ contents (Ruiz-Lozano et al. 2001) and also higher Gi-1 transcript levels. However, according to Schubert (1986), N derived from $\mathrm{N}_{2}$-fixation (as ammonia) is made directly available to the host plant via the root nodule, and thus, it is not expected that the mycorrhizal fungus could be involved in the transport and transfer of such $\mathrm{N}$ to the host plant. Hence, it is possible that Gi-1 is involved in an intermediary step of the synthesis of amides, ureides, amino acids, or proteins and that the amount of $\mathrm{N}$ available in the roots modulates $\mathrm{Gi}-1$ gene expression. To support this hypothesis, we observed in this study that drought stress significantly decreased Gi-1 transcript accumulation both in lettuce and in soybean roots. Drought stress has been shown to reduce $\mathrm{N}$ availability for plants by reducing its flux to the root (Azcón et al. 1996; Tobar et al. 1994b) and this could explain the lower Gi-1 transcript levels in droughtstressed lettuce roots. In the same way, drought stress causes premature root nodule senescence in legume plants, decreasing their ability for $\mathrm{N}_{2}$-fixation (Gogorcena et al. 1995; RuizLozano et al. 2001). The drought-stressed soybean plants used in this study had a lower $\mathrm{N}$ content than their corresponding well-watered treatments (Ruiz-Lozano et al. 2001), as well as having decreased Gi-1 transcript levels.

In conclusion, we have identified a gene from the AM fungus $G$. intraradices which is expressed at high levels during AM symbiosis and which is up-regulated by $\mathrm{N}$ availability in the root. Our current hypothesis is that the $G i-1$ gene product has a role in the synthesis of nitrogen compounds.

\section{MATERIALS AND METHODS}

\section{Plant inoculation and growth conditions.}

Seeds of Lactuca sativa L. cv. Romana were inoculated at sowing time with one of two AM species as described previously (Ruiz-Lozano et al. 2000). The AM species were $G$. intraradices (Schenck and Smith) isolate BEG 121 or $G$. mosseae (Nicol. and Gerd.) Gerd. and Trappe, isolate BEG 122. Uninoculated plants received the same amount of autoclaved inoculum together with a 2-ml aliquot of a filtrate $(<20$ $\mu \mathrm{m}$ ) of the AM inoculum in order to provide a general micro-

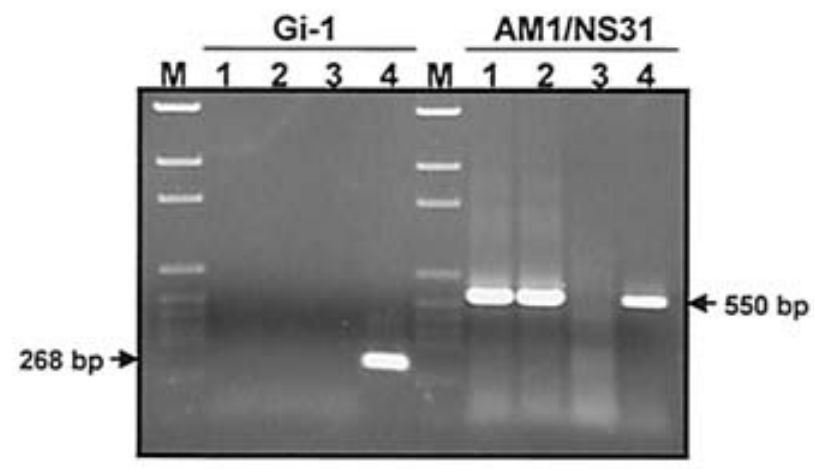

Fig. 4. Electrophoresis on $1.2 \%$ agarose gel for reverse transcription-polymerase chain reaction products obtained with specific primers designed on Gi-1 sequence or with ribosomal primers and cDNA of different origins. M, pGEM size marker; lane 1, ungerminated spores; lane 2, germinating spores; lane 3, negative control reaction without RT; lane 4, positive control (cDNA from lettuce roots colonized by Glomus intraradices). bial population free of AM propagules. Four seeds were sown in plastic pots containing $500 \mathrm{~g}$ of a sterilized soil/sand mixture $(1: 1, \mathrm{vol} / \mathrm{vol})$ and thinned after emergence to leave one seedling per pot. The soil characteristics were as described previously (Ruiz-Lozano et al. 2000).

In a second experiment, soybean (Glycine max L. cv. Williams) seeds were sterilized in a $15 \% \mathrm{H}_{2} \mathrm{O}_{2}$ solution for 8 min, then washed several times with sterile water to remove any trace of chemical that could interfere in seed germination and placed on sterile vermiculite at $25^{\circ} \mathrm{C}$ to germinate. Threeday-old seedlings were transferred to plastic pots containing $600 \mathrm{~g}$ of sterilized soil/sand mixture $(1: 1, \mathrm{vol} / \mathrm{vol})$. Inoculum of $G$. intraradices isolate BEG $121(10 \mathrm{~g})$ was added to the pots at sowing time just below soybean seedlings. When appropriate, a suspension ( $2 \mathrm{ml}$ of seed) of the diazotrophic bacterium B. japonicum strain USDA $110\left(10^{9}\right.$ cell $\left.\mathrm{ml}^{-1}\right)$ was sprinkled over the seedling at the time of planting. Nonnodulated plants received $3 \mathrm{mM}$ of $\mathrm{NH}_{4} \mathrm{NO}_{3}$, in an attempt to obtain plants of size and nutrient content similar to those in the nodulated treatment (Ruiz-Lozano et al. 2001).

Plants were grown in a controlled environmental chamber with 70 to $80 \%$ relative humidity, day and night temperatures of 25 and $15^{\circ} \mathrm{C}$, respectively, and a photoperiod of $16 \mathrm{~h}$ at a Photosynthetic photon flux density (PPFD) of 460 to $500 \mu \mathrm{mol}$ $\mathrm{m}^{-2} \mathrm{~s}^{-1}$ (model LI-188B; Licor, Lincoln, NE, U.S.A.). For the time-course experiment with lettuce plants colonized by $G$. intraradices, plants were harvested 7, 14, 21, or 35 dai. The rest of the plants (lettuce and soybean) were harvested 45 days after starting the experiment.

For both plant experiments, soil water potential $(\Psi)$ was determined as previously described (Ruiz-Lozano et al. 2001). Water was supplied daily to maintain constant soil water potential close to $-0.04 \mathrm{MPa}$ (field capacity) during the first 5 weeks of plant growth. At that time, a group of plants in each experiment was drought stressed by allowing them to dry until soil water potential reached $-0.17 \mathrm{MPa}$; they were maintained under such conditions for a further 10 days. In order to control the level of water stress, pots were weighed daily (at the end of the afternoon) and the amount of water lost was added to the pot in order to maintain soil $\Psi$ close to $-0.17 \mathrm{MPa}$ during the entire drought period.

To determine the effect of $\mathrm{N}$ and $\mathrm{P}$ fertilization on Gi-1 expression, lettuce plants inoculated with $G$. intraradices were fertilized with $4 \mathrm{mM} \mathrm{NH} \mathrm{NO}_{3}, 0.5 \mathrm{mM} \mathrm{KH}_{2} \mathrm{PO}_{4}$, or both. Two weeks after planting, plants were fertilized weekly by adding a diluted $\mathrm{N}$ or $\mathrm{P}$ solution at $10 \mathrm{ml} \mathrm{week}^{-1}$ pot $^{-1}$, so that the total amount provided at the end of the experiment reached the desired $4 \mathrm{mM}$ of $\mathrm{N}$ or $0.5 \mathrm{mM}$ of $\mathrm{P}$. At harvest, shoot dry weight was measured after drying in a forced draught oven at $70^{\circ} \mathrm{C}$ for 2 days. Concentration of $\mathrm{N}$ (micro-Kjeldahl) in root tissues was measured. Parameters of mycorrhizal colonization were determined after trypan blue staining of roots (Trouvelot et al.

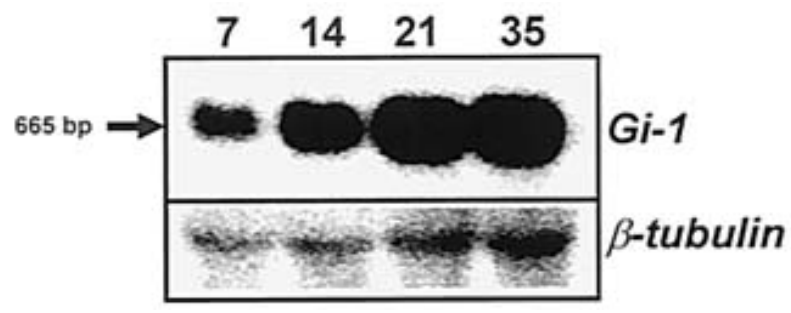

Fig. 5. Northern blot of root total RNA $(20 \mu \mathrm{g})$ from Glomus intraradices colonized lettuce plants. Plants were harvested at $7,14,21$, or 35 days after inoculation. Blots were hybridized with the Gi-1 probe and with the $G$. intraradices $\beta$-tubulin probe (accession number BE603903) for calibration of $\mathrm{Gi}-1$ gene expression. 
1986) in five replicate plants for each treatment. Percentages were arcsin transformed, and data were subjected to analysis of variance. Differences among means were analyzed for significance by Duncan's multiple range test (Duncan 1955).

\section{RNA isolation, construction}

of the cDNA library, and screening.

Total RNA was extracted from lettuce roots heavily colonized (more than $90 \%$ of root length) with $G$. intraradices by phenol/chloroform extraction (Kay et al. 1987) and used for polyA isolation with the PolyAtract mRNA isolation system (Promega Corp., Madison, WI, U.S.A.). cDNA was synthesized from $5 \mu \mathrm{g}$ of polyA RNA and cloned into the bacteriophage lambda ExCell vector (Amersham, Little Chalfont, U.K.). The library was screened by differential hybridization of identical plaque lifts. Approximately $10^{4} \lambda$ bacteriophage particles were plated at low density (1,500 to 2,000 PFU per plate) on the host Escherichia coli (strain NM522). After incubation for 7 to $8 \mathrm{~h}$ at $37^{\circ} \mathrm{C}$, the colonies were produced, and the petri plates placed at $4^{\circ} \mathrm{C}$ for $1 \mathrm{~h}$ to harden the top agarose. They were then overlaid with a Hybond- $\mathrm{N}^{+}$nylon membrane (Amersham) and left for $2 \mathrm{~min}$ at room temperature or $4 \mathrm{~min}$ for duplicate filters. DNA was denatured and fixed by autoclaving the filter for $5 \mathrm{~min}$ at $120^{\circ} \mathrm{C}$. Each of the duplicate filters was then hybridized at $65^{\circ} \mathrm{C}$ with a total cDNA radioactive probe from mycorrhizal roots or from uninoculated control roots under standard conditions (Sambrook et al. 1989). After washing twice for $5 \mathrm{~min}$ at room temperature in $2 \times \mathrm{SSC}$ ( $1 \times \mathrm{SSC}$ is $0.15 \mathrm{M} \mathrm{NaCl}$ plus $0.015 \mathrm{M}$ sodium citrate) and $0.1 \%$ sodium dodecyl sulfate (SDS) and once for $15 \mathrm{~min}$ at $65^{\circ} \mathrm{C}$ in $0.5 \times \mathrm{SSC}$ and $0.1 \% \mathrm{SDS}$, membranes were exposed overnight to Kodak X-RAY-OMAT at $-70^{\circ} \mathrm{C}$.

Differentially detected phage clones were used as template for PCR-based screening with universal M13 forward and reverse primers in order to verify the purity of the clones as well as the size of the inserts. The PCR products obtained were divided into two equal fractions, separated in agarose gels, and transferred onto nylon membranes (Martin-Laurent et al.

Table 3. Mycorrhizal colonization reached by Glomus intraradices ${ }^{\mathrm{z}}$

\begin{tabular}{lccc}
\hline Harvest time & $\boldsymbol{F}(\boldsymbol{\%})$ & $\boldsymbol{M}(\boldsymbol{\%})$ & $\boldsymbol{A}(\boldsymbol{\%})$ \\
\hline 7 dai & $27 \mathrm{c}$ & $30 \mathrm{c}$ & $25 \mathrm{~b}$ \\
15 dai & $45 \mathrm{~b}$ & $35 \mathrm{c}$ & $30 \mathrm{~b}$ \\
21 dai & $87 \mathrm{a}$ & $50 \mathrm{~b}$ & $88 \mathrm{a}$ \\
35 dai & $92 \mathrm{a}$ & $71 \mathrm{a}$ & $81 \mathrm{a}$ \\
\hline
\end{tabular}

${ }^{\mathrm{z}}$ On lettuce roots harvested $7,15,21$, or 35 days after inoculation (dai). $F=$ colonization frequency, $M=$ colonization intensity, and $A=$ arbuscule richness. Numbers in a column followed by the same letter are not significantly different $(P<0.05)$ as determined by Duncan's multiple range test.

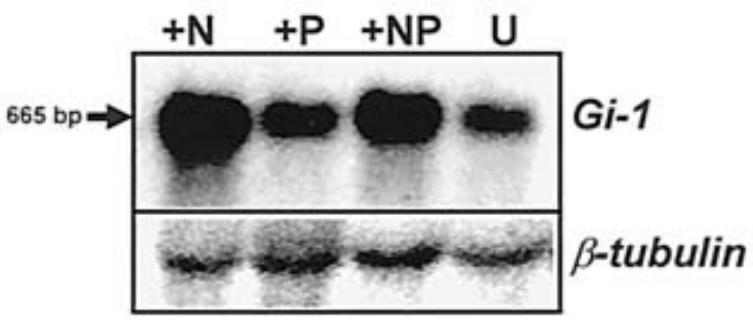

Fig. 6. Northern blot of root total RNA $(20 \mu \mathrm{g})$ from Glomus intraradicescolonized lettuce plants. Plants were either fertilized with $4 \mathrm{mM} \mathrm{NH}_{4} \mathrm{NO}_{3}$ $(+\mathrm{N}), 0.5 \mathrm{mM} \mathrm{KH}_{2} \mathrm{PO}_{4}(+\mathrm{P})$, or both nutrients $(+\mathrm{NP})$, or unfertilized $(\mathrm{U})$. Blots were hybridized with the Gi-1 probe and with the $G$. intraradices $\beta$ tubulin probe (accession number BE603903) for calibration of $\mathrm{Gi}-1$ gene expression.
1995). Southern blot analysis was used to confirm differentially expressed clones by probing the membranes with ${ }^{32} \mathrm{P}-\mathrm{la}-$ beled cDNA from mycorrhizal and control lettuce roots. Differentially detected phage clones were submitted to in vivo excision on the pExCell phagemid as recommended by the manufacturer (Amersham).

\section{Plant and fungal DNA isolation and PCR.}

Plant DNA was extracted by the method described by Dellaporta and associates (1983). Fungal DNA was extracted as previously described (Ruiz-Lozano and Bonfante 2000).

Genomic DNA (50 ng) from lettuce leaves and from G. intraradices-colonized lettuce and pea roots, as well as from $G$. intraradices spores, served as templates for PCR with $0.5 \mu \mathrm{M}$ concentrations of specific primer designed on the Gi- 1 sequence (primer forward 5'-CTTACCCAGAGAAAATAAC G3'; primer reverse 5' CCTGCTCGAATCAATATCC-3'), 100 $\mu \mathrm{M}$ dNTPs, $1 \times$ PCR buffer (Sigma-Aldrich, St. Louis), 2.5 $\mathrm{mM} \mathrm{MgCl}_{2}$, and $0.25 \mathrm{U}$ Taq DNA polymerase (SigmaAldrich). A Perkin-Elmer/Cetus DNA Thermal Cycler was employed with the following parameters: initial denaturation at $95^{\circ} \mathrm{C}$ for $4 \mathrm{~min}$, followed by 30 cycles of denaturation at $94^{\circ} \mathrm{C}$ for $30 \mathrm{~s}$, annealing at $56^{\circ} \mathrm{C}$ for $45 \mathrm{~s}$, elongation at $72^{\circ} \mathrm{C}$ for 45 $\mathrm{s}$, and a final elongation at $72^{\circ} \mathrm{C}$ for $5 \mathrm{~min}$. PCR products were separated in a $1.2 \%$ agarose gel for visualization by ethidium bromide staining and later Southern blot hybridization with the Gi-1 probe under standard conditions (Sambrook et al. 1989).

\section{RT-PCR.}

Total RNA was extracted from surface-sterilized (3\% chloramine $\mathrm{T}, 0.03 \%$ streptomycin for $20 \mathrm{~min}$ ) dormant and germinating (water) spores of $G$. intraradices using RNeasy Plant Mini Kit (Qiagen, Hilden, Germany) and then subjected to DNase treatment according to Promega's recommendations. Total RNA (500 ng) from both treatments or from $G$. intraradices-infected lettuce roots was reverse transcribed to first

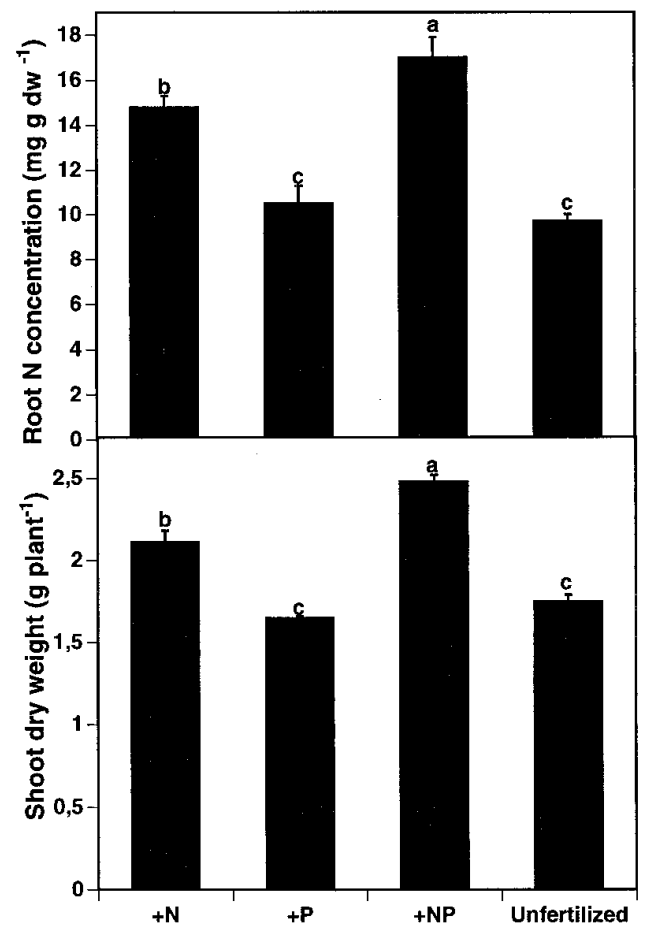

Fig. 7. Shoot dry weight $\left(\mathrm{g} \mathrm{plant}^{-1}\right)$ and root $\mathrm{N}$ concentration $\left(\mathrm{mg} \mathrm{g} \mathrm{dw}{ }^{-1}\right)$ of lettuce plants colonized by Glomus intraradices and either unfertilized or fertilized with $4 \mathrm{mM} \mathrm{NH}_{4} \mathrm{NO}_{3}(+\mathrm{N}), 0.5 \mathrm{mM} \mathrm{KH}_{2} \mathrm{PO}_{4}(+\mathrm{P})$, or both nutrients $(+\mathrm{NP})$. 


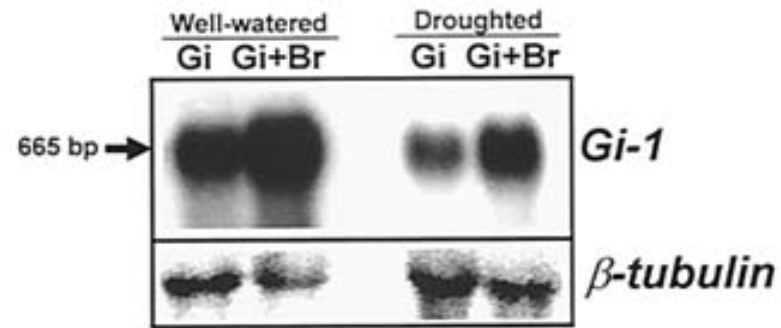

Fig. 8. Northern blot of root total RNA $(20 \mu \mathrm{g})$ soybean plants single inoculated with Glomus intraradices (Gi) or dually inoculated with the arbuscular mycorrhizal fungus plus Bradyrhizobium japonicum $(\mathrm{Gi}+\mathrm{Br})$. Plants were cultivated either under well-watered conditions or subjected to drought stress before harvest. Blots were hybridized with the Gi-1 probe and with the $G$. intraradices $\beta$-tubulin probe (accession number BE603903) for calibration of Gi-1 gene expression.

strand cDNA using AMV-RT enzyme (Finnzymes, Espoo, Finland) and either NS31 primer (Simon et al. 1992) or oligo(dT) $)_{15}$ primer (Promega Corp.) in a final volume of $25 \mu \mathrm{l}$ with the buffer and temperature recommended by the enzyme supplier. Aliquots $(1 \mu \mathrm{l})$ of the obtained cDNA were used for PCR, either with the specific primers designed on Gi-1 sequence or with AM1 (Helgason et al. 1998) and NS31, under conditions similar to those described above.

\section{Sequencing the cloned cDNA and analyses.}

Sequencing was performed by the dideoxy-sequencing method (Sanger et al. 1977) using fluorescent dye-linked universal M13 primers and a Perkin-Elmer ABI Prism model 373 DNA sequencer. Similarity searches were carried out in the EMBL databank using the FASTA program or the BLAST software available online from the National Center for Biotechnology Information.

\section{Northern blot analysis.}

Northern blot analysis was performed as described previously (Ruiz-Lozano et al. 1999). Briefly, after electrophoresis on $1.2 \%$ agarose gel containing $2.2 \mathrm{M}$ formaldehyde, total RNA $(20 \mu \mathrm{g})$ was blotted onto Hybond- $\mathrm{N}^{+}$nylon membranes (Amersham) by capillarity (Sambrook et al. 1989). Blots were prehybridized 2 to $3 \mathrm{~h}$ at $62^{\circ} \mathrm{C}$ in $6 \times$ Denhardt's solution, $5 \times$ SSC, and $0.5 \%$ SDS and hybridized with a Gi-1 probe obtained by radioactive PCR labeling of plasmid insert. Unincorporated ${ }^{32} \mathrm{P}$ was removed using Mini Quick Spin columns (Boehringer Manheim, Indianapolis, IN, U.S.A.). A total of $10^{7} \mathrm{cpm}$ probe was heat denatured and used to hybridize the blots overnight at $62^{\circ} \mathrm{C}$ under standard conditions (Sambrook et al. 1989). After washing twice for $5 \mathrm{~min}$ at room temperature in $2 \times \mathrm{SSC}$ and $0.1 \% \mathrm{SDS}$ and once for $15 \mathrm{~min}$ at $57^{\circ} \mathrm{C}$ in the same solution, membranes were exposed overnight to Kodak X-RAY-OMAT at $-70^{\circ} \mathrm{C}$. Blots were subsequently hybridized with the $\beta$-tubulin gene probe from $G$. intraradices (accession number BE603903) under the conditions mentioned above. Gi-1 and $\beta$-tubulin signals on autoradiograms were analyzed and quantified using Quantity One software (BioRad, Hemel Hempstead, U.K.). Transcript accumulation levels were normalized according to $\beta$-tubulin signals on autoradiograms. Northern blot analyses were repeated twice using two different sets of plants and RNA for all treatments.

\section{ACKNOWLEDGMENTS}

We thank P. Jeffries, University of Kent, for correcting the English text and P. Lammers, New Mexico State University, for providing us with the $G$. intraradices $\beta$-tubulin probe. This work was financed by CICYTFEDER (Project 1FD97-0507-C02-01).

\section{LITERATURE CITED}

Alexander, T., Meier, R., Thoth, R., and Weber, H. C. 1988. Dynamics of arbuscule development and degeneration in mycorrhizas of Triticum estivum L. and Avena sativa L. with reference to Zea mays L. New Phytol. 110:363-370.

Azcón, R., Gómez, M., and Tobar, R. M. 1992. Effects of nitrogen source on growth, nutrition, photosynthetic rate and nitrogen metabolism of mycorrhizal and phosphorus-fertilized plants of Lactuca sativa L. New Phytol. 121:227-234.

Azcón, R., Gómez, M., and Tobar, R. M. 1996. Physiological and nutritional responses by Lactuca sativa $\mathrm{L}$. to nitrogen sources and mycorrhizal fungi under drought conditions. Biol. Fertil. Soils 22:156-161.

Barker, S. J., Tagu, D., and Delp, G. 1998. Regulation of root and fungal morphogenesis in mycorrhizal symbiosis. Plant Physiol. 116:12011207

Burleigh, S. H. 2000. Cloning arbuscule-related genes from mycorrhizas. Plant Soil 226:287-292.

Burleigh, S. H., and Harrison, M. J. 1997. A novel gene whose expression in Medicago truncatula roots is suppressed in response to colonization by vesicular-arbuscular mycorrhizal (VAM) fungi and to phosphate nutrition. Plant Mol. Biol. 34:199-208.

Burleigh, S. H., and Harrison, M. J. 1998. A cDNA from the arbuscular mycorrhizal fungus Glomus versiforme with homology to a cruciform DNA-binding protein from Ustilago maydis. Mycorrhiza 7:301-306.

Dellaporta, S. L., Wood, J., and Hicks, J. B. 1983. A plant DNA minipreparation. Plant Mol. Biol. Rep. 1:19-21.

Delp, G., Smith, S. E., and Barker, S. J. 2000. Isolation by differential display of three partial cDNAs potentially coding for proteins from the VA mycorrhizal Glomus intraradices. Mycol. Res. 104:293-300.

Duncan, D. B. 1955. Multiple range and multiple F-tests. Biometrics 11:142.

Faure, S., Cliquet, J. B., Thephany, G., and Boucaud, J. 1998. Nitrogen assimilation in Lolium perenne colonized by the arbuscular mycorrhizal fungus Glomus fasciculatum. New Phytol. 138:411-417.

Ferrol, N., Barea, J. M., and Azcón-Aguilar, C. 2000. The plasma membrane $\mathrm{H}^{+}$-ATPase gene family in the arbuscular mycorrhizal fungus Glomus mosseae. Curr. Genet. 37:112-118.

Franken, P., and Gianinazzi-Pearson, V. 1996. Construction of Genomic phage libraries of the arbuscular mycorrhizal fungi Glomus mosseae and Scutellospora castanea and isolation of ribosomal RNA genes. Mycorrhiza 6:167-173.

Franken, P., Lapopin, L., Meyer-Gauen, G., and Gianinazzi-Pearson, V. 1997. RNA accumulation and genes expressed in spores of the arbuscular mycorrhizal fungus Gigaspora rosea. Mycologia 89:295-299.

Franken, P., and Requena, N. 2001. Analysis of gene expression in arbuscular mycorrhizas: new approaches and challenges. New Phytol. 150:517-523.

Gogorcena, Y., Iturbe-Ormaetxe, I., Escuredo, P. R., and Becana, M. 1995. Antioxidant defense against activated oxygen in pea nodules subjected to water stress. Plant Physiol. 108:753-759.

Harrier, L. A. 2001. The arbuscular mycorrhizal symbiosis: a molecular review of the fungal dimension. J. Exp. Bot. 52:469-478.

Harrier, L. A., Wright, F., and Hooker, J. E. 1998. Isolation of the $3-$ phosphoglycerate kinase gene from the arbuscular mycorrhizal fungus Glomus mossae (Nicol. and Gerd.) Gerdemann and Trappe. Curr. Genet. 34:386-392.

Harrison, M. J., and van Buuren, M. L. 1995. A phosphate transporter from the mycorrhizal fungus Glomus versiforme. Nature 378:626-629.

Helgason, T., Daniell, T. J., Husband, R., Fitter, A. H., and Young, J. P. W. 1998. Ploughing up the wood-wide web? Nature 394:431.

Johansen, A. 1999. Depletion of soil mineral N by roots of Cucumis sativus L. colonized or not by arbuscular mycorrhizal fungi. Plant Soil 209:119-127.

Johansen, A., Jakobsen, I., and Jensen, E. S. 1993. Hyphal transport by a vesicular-arbuscular mycorrhizal fungus of $\mathrm{N}$ applied to the soil as ammonium or nitrate. Biol. Fertil. Soils 16:66-70.

Kaldorf, M., Schmelzer, E., and Bothe, H. 1998. Expression of maize and fungal nitrate reductase genes in arbuscular mycorrhiza. Mol. PlantMicrobe Interact. 11:439-448.

Kaldorf, M., Zimmer, W., and Bothe, H. 1994. Genetic evidence for the occurrence of assimilatory nitrate reductase. Mycorrhiza 5:23-28.

Kay, R., Chau, A., and Daly, M. 1987. Duplication of CaMV 35S promoter sequences creates a strong enhancer for plants genes. Science 236:1299-1302.

Koide, R. T., and Schreiner, K. P. 1992. Regulation of the vesicular-arbuscular mycorrhizal symbiosis. Annu. Rev. Plant Physiol. Plant Mol. Biol. 43:557-581.

Krajinski, F., Biela, A., Schubert, D., Gianinazzi-Pearson, V., Kaldenhoff, R., and Franken, P. 2000. Arbuscular mycorrhiza development regulates 
the mRNA abundance of Mtaqp1 encoding a mercury-insensitive aquaporin of Medicago truncatula. Planta 211:85-90.

Lanfranco, L., Vallino, M., and Bonfante, P. 1999. Expression of chitin synthase genes in the arbuscular mycorrhizal fungus Gigaspora margarita. New Phytol. 142:347-354.

Liu, H., Trieu, A. T., Blaylock, L. A., and Harrison, M. J. 1998. Cloning and characterization of two phosphate transporters from Medicago truncatula roots: Regulation in response to phosphate and to colonization by arbuscular mycorrhizal (AM) fungi. Mol. Plant-Microbe Interact. 11:14-22.

Mäder, P., Vierheilig, H., Streitwolf-Engel, R., Boller, T., Frey, B., Christie, P., and Wienken, A. 2000. Transport of ${ }^{15} \mathrm{~N}$ from a soil compartment separated by a polytetrafluoroethylene membrane to plant roots via the hyphae of arbuscular mycorrhizal fungi. New Phytol. 146:155-161.

Marschner, H. 1986. Functions of mineral nutrients: Macronutrients. Pages 195-267 in: Mineral Nutrition of Higher Plants. H. Marschner, ed. Academic Press, London.

Martin, F. 2001. Frontiers in molecular mycorrhizal research - genes, loci, dots, and spins. New Phytol. 150:499-507.

Martin-Laurent, F., Franken, P., and Gianinazzi, S. 1995. Screening of cDNA fragments generated by differential RNA display. Anal. Biochem. 228:182-184.

Martin-Laurent, F., van Tuinen, D., Dumas-Gaudot, E., GianinazziPearson, V., Gianinazzi, S. and Franken, P. 1997. Differential display analysis of RNA accumulation in arbuscular mycorrhiza of pea and isolation of a novel symbiosis-regulated plant gene. Mol. Gen. Genet. 256:37-44.

Murphy, P. J., Langridge, P., and Smith, S. E. 1997. Cloning plant genes differentially expressed during colonization of roots of Hordeum vulgare by the vesicular-arbuscular mycorrhizal fungus Glomus intraradices. New Phytol. 135:291-301.

Newsham, K. K., Fitter, A. H., and Watterson, A. R. 1995. Arbuscular mycorrhiza protect an annual grass from root pathogenic fungi in the field. J. Ecol. 83:991-1000.

Pirozynski, K. A., and Malloch, D. W. 1975. The origin of land plants: A matter of mycotrophism. Biosystems 6:153-164.

Requena, N., Mann, P., and Franken, P. 2000. A homologue of the cell-cycle check-point TOR2 from Saccharomyces cerevisiae exists in the arbuscular mycorrhizal fungus Glomus mosseae. Protoplasma 212:89-98.

Ricken, B., and Hofner, W. 1996. Effect of arbuscular mycorrhizal fungi (AMF) on heavy metal tolerance of alfalfa (Medicago sativa $\mathrm{L}$ ) and oat (Avena sativa $\mathrm{L}$ ) on a sewage-sludge treated soil. Z. Pflanzenernaehr. Bodenkd. 159:189-194.

Ruiz-Lozano, J. M., Azcón, R., and Gómez, M. 1995. Effects of arbuscular-mycorrhizal Glomus species on drought tolerance: Physiological and nutritional plant responses. Appl. Environ. Microbiol. 61:456-460.

Ruiz-Lozano, J. M., and Bonfante, P. 2000. A Burkholderia strain living inside the arbuscular-mycorrhizal fungus Gigaspora margarita possesses the $v a c B$ gene, which is involved in host cell colonization by bacteria. Microbial Ecol. 39:137-144.

Ruiz-Lozano, J. M., Collados, C., Barea, J. M., and Azcón, R. 2001.
Arbuscular mycorrhizal symbiosis can alleviate drought-induced nodule senescence in soybean plants. New Phytol. 151:493-502.

Ruiz-Lozano, J. M., Gómez, M., Nuñez, R., and Azcón, R. 2000. Mycorrhizal colonization and drought stress affect $\delta^{13} \mathrm{C}$ in ${ }^{13} \mathrm{CO}_{2}$-labeled lettuce plants. Physiol. Plant. 109:268-273.

Ruiz-Lozano, J. M., Roussel, H., Gianinazzi, S., and Gianinazzi-Pearson, V. 1999. Defense genes are differentially induced by a mycorrhizal fungus and Rhizobium sp. in wild-type and symbiosis-defective pea genotypes. Mol. Plant-Microbe Interact. 12:976-984.

Sambrook, J., Fritsch, E. F., and Maniatis, T. A. 1989. Molecular Cloning: A Laboratory Manual. 2nd ed. Cold Spring Harbor Laboratory Press. Cold Spring Harbor, NY.

Sanger, F., Nicklen, S., and Coulsen, A. R. 1977. DNA sequencing with chain terminating inhibitors. Proc. Natl. Acad. Sci. U.S.A. 74:5463 5467.

Sawaki, H., and Saito, M. 2001. Expressed genes in the extraradical hyphae of an arbuscular mycorrhizal fungus, Glomus intraradices, in the symbiotic phase. FEMS (Fed. Eur. Microbiol. Soc.) Microbiol. Lett. 195:109-113.

Schubert, K. R. 1986. Products of biological nitrogen fixation in higher plants: synthesis, transport, and metabolism. Annu. Rev. Plant Physiol. 35:539-574.

Simon, L., Bousquet, J., and Bruns, T. D. 1992. Specific amplification of $18 \mathrm{~S}$ fungal ribosomal genes from vesicular-arbuscular endomycorrhizal fungi colonizing roots. Appl. Environ. Microbiol. 58:291-295.

Smith, S. E., and Gianinazzi-Pearson, V. 1988. Physiological interactions between symbionts in vesicular arbuscular mycorrhizal plants. Ann Rev. Plant Physiol. Plant Mol. Biol. 39:221-244.

Smith, S. E., and Read, D. J. 1997. Mycorrhizal Symbiosis. Academic Press, New York.

Smith, S. E., and Smith, F. A. 1990. Structure and function of the interfaces in biotrophic symbioses as they relate to nutrient transport. New Phytol. 114:1-38.

Stommel, M., Mann, P., and Franken, P. 2001. EST-library construction using spore RNA of the arbuscular mycorrhizal fungus Gigaspora rosea. Mycorrhiza 10:281-285.

Tobar, R. M., Azcón, R., and Barea, J. M. 1994a. Improved nitrogen uptake and transport from ${ }^{15} \mathrm{~N}$-labeled nitrate by external hyphae of arbuscular mycorrhiza under water-stressed conditions. New Phytol. 126:119-122.

Tobar, R. M., Azcón, R., and Barea, J. M. 1994b. The improvement of plant $\mathrm{N}$ acquisition from an ammonium-treated, drought-stressed soil by the fungal symbiont in arbuscular mycorrhizae. Mycorrhiza 4:105-108.

Trouvelot, A., Kough, J. L., and Gianinazzi-Pearson, V. 1986. Mesure du taux de mycorhization VA d'un système radiculaire. Recherche de méthodes d'estimation ayant une signification fonctionnelle. Pages 217-221 in: Physiological and Genetical Aspects of Mycorrhizae. V. GianinazziPearson and S. Gianinazzi, eds. INRA Press, Paris.

van Buuren, M. L., Maldonado-Mendoza, I. E., Trieu, A. T., Blaylock, L. A., and Harrison, M. J. 1999. Novel genes induced during an arbuscular mycorrhizal (AM) symbiosis formed between Medicago truncatula and Glomus versiforme. Mol. Plant-Microbe Interact. 12:171-181. 